Asian J. Med. Biol. Res. 2019, 5 (2), 146-152; doi: 10.3329/ajmbr.v5i2.42496

\author{
Asian Journal of \\ Medical and Biological Research \\ ISSN 2411-4472 (Print) 2412-5571 (Online) \\ www.ebupress.com/journal/ajmbr
}

\title{
Article \\ Awareness and practice of female genital mutilation/cutting in a semi-urban community in southwest Nigeria
}

AWOLEKE Adeola Olabisi ${ }^{1}$, AWOLEKE Jacob Olumuyiwa ${ }^{2 *}$ and IBRAHIM Blessing Saidat ${ }^{3}$

${ }^{1}$ Ekiti State University Teaching Hospital School of Nursing, Ado - Ekiti, Nigeria

${ }^{2}$ Department of Obstetrics and Gynaecology, Ekiti State University, Ado-Ekiti, Nigeria

${ }^{3}$ Department of Nursing Science, Ladoke Akintola University of Technology, Ogbomosho, Nigeria

*Corresponding author: Dr. Awoleke, J. O., Ekiti State University Teaching Hospital, P.M.B. 5355, Ado-Ekiti, Nigeria. Phone: +234806 328 9272; E-mail: bisijacob@yahoo.co.uk

Received: 05 June 2019/Accepted: 29 June 2019/ Published: 30 June 2019

\begin{abstract}
Despite efforts to eliminate female genital mutilation and cutting, the harmful practice has persisted in southwest Nigeria. There is an urgent need for accurate data highlighting predictors of the practice so that interventions to eliminate it can be effective. A population-based, cross-sectional survey of women in Ado Ekiti Local Government Area was conducted to address this need. FGM/C prevalence was $67.2 \%$, and 94\% of the women interviewed were aware of the practice. Although most, 142 (39.3\%), of the women heard of FGM/C from healthcare personnel, half, $181(50.1 \%)$, of the respondents noted that healthcare providers performed the FGM/C in the community. Young and middle-aged women, of Yoruba extraction who were married, and multiparous, were significantly more likely to have undergone FGM/C. Also, the likelihood of having experienced FGM/C was more among women who were presently employed (irrespective of the class of occupation), had female children, and with a poor perception about FGM/C. After including characteristics with $\mathrm{p}<0.05$ into multivariate logistic regression model with practice of FGM/C as the dependent variable, perception about FGM/C (AOR: 0.42; 95\% C.I.: $0.24-0.72 ; \mathrm{p}=0.002$ ), employment as a skilled worker (AOR: 0.30; 95\% C.I.: $0.13-0.69 ; \mathrm{p}=0.005$ ) and being of Yoruba (AOR: 0.07; 95\% C.I.: $0.02-0.25 ; \mathrm{p}<0.0001$ ) and Igbo extraction (AOR: 0.15; 95\% C.I.: $0.02-0.93$; $\mathrm{p}=0.042$ ), were independently associated with the experience of FGM/C in the study population. Scaling up media involvement and inclusion of FGM/C facts in school texts and curricula, legal sanctions for erring healthcare workers, female re-orientation to correct wrong perception about FGM/C's supposed benefits, and accurate data for targeted public health interventions are recommended.
\end{abstract}

Keywords: female circumcision; medicalization; self report; public health; Nigeria

\section{Introduction}

Female genital mutilation and cutting (FGM/C) refers to the partial or total removal of the external female genitalia or other injury to the female genital organs for non-medical reasons (Banks et al., 2006). Over 200 million women and girls alive today have undergone FGM/C, and about three million more are at risk annually (WHO, 2008; UNICEF, 2016). Diverse complications, ranging from immediate morbidities like tetanus, HIV infection, anaemia, and life-threatening bleeding, to longer term disorders such as persistent perineal pain, inclusion cysts, sexual dysfunction, post-traumatic stress disorder, anxiety, and marital disharmony have been documented. Also, FGM/C has been linked with increased risk of caesarean delivery, postpartum haemorrhage, de-infibulation, difficult/prolonged labour, severe obstetric tears, extended maternal hospital stay, increased neonatal resuscitation at delivery, stillbirth and neonatal death. Generally, the more severe the mutilation, the more serious the complications (Banks et al., 2006; Yoder et al., 2004; Elnashar and Abdelhady, 2007; Almroth et al., 2005; Ogunlola et al., 2003; Owojuyigbe et al., 2017). 
Efforts to eliminate the practice, which were pioneered by missionaries to Kenya in the early $20^{\text {th }}$ century, have snowballed into commitment by international bodies to stamp out FGM/C (Caldwell et al., 2000). In 2012, the United Nations General Assembly made a resolution calling the world to put an end to FGM/C. Thereafter, in September 2015, the global community resolved, as a target under Goal 5 of the Sustainable Development Goals (SDGs), to eliminate all harmful practices (including FGM/C) by 2030. Going forward, the Federal Government of Nigeria, through an act of the National Assembly, criminalized FGM/C by passing the Violence Against Persons (Prohibition) [VAPP] Act 2015. The Act not only sanctions violators, but also ensures compensation and rehabilitation of victims (Mberu, 2017). However, these anti-FGM/C efforts have often been weak, with limited evidence of their effectiveness, especially in countries with the highest prevalence worldwide like Nigeria. For example, serial demographic surveys in Nigeria have revealed that FGM/C is quite prevalent, with only minimal reduction in its practice occurring over a long time. The Yoruba and Igbo ethnic groups continue to have the highest prevalence of $>70 \%$ each, compared with a national prevalence of $25 \%$ (National Population Commission, 2014). In spite of legislation, advocacy, and attempts at raising the awareness of the citizens about the harmful effects of $\mathrm{FGM} / \mathrm{C}$, the practice has persisted in Nigeria. It is obvious that these modalities have played a limited role in the elimination of FGM/C, thus highlighting the need to obtain accurate data that will identify factors promoting the perpetuation of its practice among geopolitical zones and ethnic groups. These will serve as evidence-base for the design of public health interventions, and inform locallyeffective anti-FGM/C policy, implementation and monitoring. Thus, this study aims to contribute to FGM/C research and intervention strategies specifically in Ekiti State, and generally in Nigeria.

\section{Materials and Methods}

This population-based, descriptive cross-sectional study about awareness and practice of FGM/C was conducted in southern Nigeria between March and May, 2019. Ado - Ekiti, the only city in Ado - Ekiti Local Government Area and the study location, is the biggest city in Ekiti State in southern Nigeria, with a human population of 308,621, who are mostly Yoruba-speaking Christians (National Population Commission, 2006). The city is home to two universities (Ekiti State University and the privately-owned Afe Babalola University), two polytechnics (Federal Polytechnic and the privately-owned Crown Polytechnic), two television stations (Nigerian Television Authority and Broadcasting Service of Ekiti State), and two radio stations (Progress FM and Voice FM). There is a Teaching Hospital, Comprehensive Health Centre, and eight Basic Health Centres serving the population within Ado - Ekiti, other towns in Ekiti State, and neighbouring states in Nigeria. It is also the trade centre for a farming region where yams, cassava, grains, and cotton are grown. Permission for the study was obtained from the Ado - Ekiti Local Government Authority.

To determine the sample size, we assumed a 50\% prevalence of FGM/C within the target population. Using a standard normal deviate of 1.96, at a $95 \%$ level of confidence and an error margin of 5\%, we concluded that at least 384 participants would be needed for the study. Four hundred questionnaires were distributed to allow for inappropriate responses and attrition.

There are thirteen administrative wards in the local government area studied. Five of them were chosen by stratified sampling, and two streets were selected by balloting from each ward. In these ten streets, 40 questionnaires were administered to female residents by simple random sampling technique. The study instrument, a self-developed semi-structured questionnaire, was designed to obtain information regarding the socio-demographic characteristics of the respondents; their awareness of FGM/C and its providers; knowledge about FGM/C, the immediate and long term outcomes; and their perception of the need/reasons for FGM/C. The questions that explored the respondents' knowledge included complications of FGM/C such as infections like tetanus \& HIV, narrowing of the vaginal orifice, pain during and after the procedure \& sex, prolonged labour, difficulties with sex, and possible marital disharmony etc. The women's perception on reasons for FGM/C such as prevents women from being promiscuous, prevents babies from dying, cultural passage into womanhood, for beautification, protects the woman's purity and virginity, brings honour to parents of circumcised girl/woman etc, were also examined.

The instrument was pre-tested using ten respondents in Irepodun-Ifelodun Local Government Area. This enabled us to identify the ambiguities in, and comprehensibility of the questionnaire, so that modifications could be made. The data obtained from the pilot study was not included in the analyses. When women completed the self-administered questionnaires, we took it as consent to participate in the survey. The questions were transliterated into Yoruba, by trained research assistants, for those who could not fully understand the English Language.

The primary outcome of interest was FGM/C among the women interviewed. This was explored by asking if the women 'had been cut in the genitalia (private parts) for a non-medical reason?' The responses to the questions 
on knowledge and perception followed a Likert-scale pattern, with five options, 'strongly agree,' 'agree,' 'don't know,' 'disagree,' and 'strongly disagree.' Each was assigned a numerical value of $+2,+1,0,-1$, and -2 respectively. Thus, the total score for the responses on perception about FGM/C was 22; good perception was $\geq$ 18 , while poor perception was $<18$. The total score for the questions on knowledge was $32 ; \geq 24$ was regarded as good knowledge, $16-23$ fair knowledge, and $\leq 15$ poor knowledge.

The data obtained were coded into, and analysed using the Statistical Software for the Social Sciences (SPSS) version 20 (IBM, Chicago, USA). The results were expressed as simple percentages. Univariate logistic regression analysis was done to identify the association between the characteristics of the respondents and the practice of FGM/C. Those variables with $\mathrm{p}$ value $<0.05$ were included in multivariate logistic regression analyses to identify the independent predictors for FGM/C. The results were expressed as adjusted odds ratio at $95 \%$ confidence interval (C. I.), with level of significance set at $\mathrm{p}<0.05$.

\section{Results}

From the 400 questionnaires administered within the study location, three hundred and eighty-four (96\%) were correctly completed, and the analysis was based on them. The awareness of FGM/C among the respondents, sources of information, and providers are summarized in Table 1. Majority, 361 (94\%), of the respondents were aware of FGM/C. Most, 142 (39.3\%), of the women heard of FGM/C from healthcare personnel, followed by $142(37.1 \%)$ who got their information from family members and friends; the least source of information, 5 (1.4\%), was from school texts and classes. Sadly, more than two-thirds (67.2\%) of the study population reported having been cut in the genitals for non-medical reasons. Half, 181 (50.1\%), of the respondents noted that healthcare providers performed the FGM/C in the community, followed by $100(27.7 \%)$ who fingered traditional birth attendants as the providers; the providers of the FGM/C service were unknown to five (1.4\%) of the respondents.

Factors associated with the practice of FGM/C in the study population were highlighted in Table 2. Young (crude odds ratio [COR]: $0.41 ; 95 \%$ confidence interval [C.I.]: $0.21-0.83 ; \mathrm{p}=0.012$ ) and middle-aged (COR: 0.15; 95\% C.I.: 0.06 - 0.35; p < 0.0001) women, of Yoruba extraction (COR: 0.09: 95\% C.I.: 0.03 - 0.32; $\mathrm{p}<$ 0.0001 ), who were married (COR: 0.35; 95\% C.I.: $0.22-0.55$; $<$ < 0.0001), and multiparous (COR: 0.44; $95 \%$ C.I.: $0.28-0.68 ; \mathrm{p}<0.0001$ ), were significantly more likely to have undergone FGM/C. Also, the likelihood of having experienced FGM/C was more among women who were presently employed (irrespective of the class of occupation) (COR: 0.28; 95\% C.I.: 0.17 - 0.47; p < 0.0001), had female children (COR: 0.36; 95\% C.I.: 0.23 0.57; $\mathrm{p}<0.0001$ ), and with a poor perception about FGM/C (COR: 0.47; 95\% C.I.: $0.29-0.77 ; \mathrm{p}=0.002)$. The educational qualification, religion and level of knowledge of the women regarding FGM/C did not influence its practice.

Our multivariate regression model (Table 3) showed that women of Yoruba extraction (adjusted odds ratio [AOR]: 0.07; 95\% C.I.: $0.02-0.25 ; \mathrm{p}<0.0001$ ), and Igbo ethnicity (AOR: 0.15; 95\% C.I.: $0.02-0.93 ; \mathrm{p}=$ 0.042), employed skilled workers (AOR: 0.30; 95\% C.I.: $0.13-0.69 ; \mathrm{p}=0.005$ ), with poor perception of FGM/C (AOR: 0.42; 95\% C.I.: $0.24-0.72 ; \mathrm{p}=0.002$ ) remained the independent predictors of FGM/C among the women studied.

\section{Discussion}

Despite efforts to stop the perpetuation of FGM/C by local, national and international bodies, the index study among a highly FGM/C-aware population clearly revealed that the practice is still prevalent in Ekiti State. High prevalence rates of genital cutting still persists in southwestern Nigeria, the indigenous home of the Yoruba tribe (Ogunlola et al., 2003; Asekun-Olarinmoye and Amusan, 2008; Dare et al., 2004). The fact that at least two out of three women interviewed self-reported having undergone FGM/C is quite alarming, considering the possible serious reproductive health consequences to the women involved, and the huge resources expended on stopping the practice. Of even greater worry is the confirmation of the 'medicalization' of FGM/C in Ado - Ekiti, with half $(50.1 \%)$ of the respondents attesting that healthcare personnel performed the procedure. Although majority, 142 (39.3\%), of the women who were aware of FGM/C heard from health personnel, it is logical to hypothesize that these healthcare personnel notified the women about the FGM/C with a view to inviting them to undergo the procedure with them! Erroneously, in many African settings, women believe that the procedure is safer when medicalized (UNICEF, 2016). Studies targeting healthcare providers in Ekiti State, with the aim of identifying their motives for its continuance, guide the development of deterrent strategies, and serve as template for monitoring and evaluation, are urgently needed. Implementing the VAPP Act 2015 to the letter, and sanctioning erring healthcare providers violating women via FGM/C are advocated. Besides, Ekiti State has a high number of in-school young people (National Population Commission, 2014); a critical preventive 
measure would be to increase the dissemination of correct FGM/C-related information by including it in school texts and curricula. Also, there is a need to scale up media involvement, especially in countering the wrong perception of the communities about the benefits of FGM/C.

Our survey found that young women were more likely to have experienced genital cutting in the study population. This confirms that FGM/C is usually carried out between infancy and adolescence. Married women with female children were also more likely to practice FGM/C. Thus, another way to eliminate the practice is female literacy, re-orientation and empowerment. When they are convinced that FGM/C is harmful, they will not likely support the cutting of their born and unborn female children (Ogunlola et al., 2003), and they can be strong advocates of a 'FGM/C-free world.'

Skilled workers were more likely to have had FGM/C. Skilled workers were likely to occupy the highest wealth quintile in their communities. This group has been found from studies in Nigeria to practice FGM/C less than those in the poorest quintile (MICS Data Nigeria, 2011). It is possible that the population in the index study were influenced by other factors stronger than their occupation or wealth. Women who had a poor perception about FGM/C were more likely to practice it. Perception affects an individual's attitude to health, and influences health-seeking practices (Akeju et al., 2016). Thus, positively influencing women's perceptions about FGM/C will be a step towards eliminating its practice.

This survey may be limited by the use of self-reportage to determine practice of FGM/C. However, studies have consistently shown that there is no significant difference between self-reported and actual status of FGM (Snow et al., 2002; Klouman et al., 2005; Larsen and Okonofua, 2002; Morison et al., 2001), implying that selfreportage of FGM/C can validly be used to assess FGM/C practice. This is even more relevant when the population is highly FGM-aware and see it as culturally acceptable.

Table 1. FGM/C awareness, sources of information and providers.

\begin{tabular}{ll}
\hline & Frequency $(\%)$ \\
\hline Awareness of FGM/C, $\boldsymbol{n}=\mathbf{3 8 4}$ & $23(6)$ \\
No & $361(94)$ \\
Yes & \\
Sources of information about FGM/C, $\boldsymbol{n}=\mathbf{3 6 1}$ & $134(37.1)$ \\
Family members and friends & $142(39.3)$ \\
Health personnel & $45(12.5)$ \\
Social media platforms & $35(9.7)$ \\
News media and tabloids & $5(1.4)$ \\
School texts and classes & \\
Experience/practice of FGM/C, $\boldsymbol{n}=\mathbf{3 8 4}$ & $126(32.8)$ \\
No & $258(67.2)$ \\
Yes & \\
FGM/C providers in the community, $\boldsymbol{n}=\mathbf{3 6 1}$ & $15(4.2)$ \\
Herbalists & $60(16.6)$ \\
Old/experienced women & $181(50.1)$ \\
Health personnel & $100(27.7)$ \\
Traditional birth attendants & $5(1.4)$ \\
Don't know & \\
\hline
\end{tabular}


Asian J. Med. Biol. Res. 2019, 5 (2)

Table 2. Univariate analysis of relationship between respondents' characteristics and FGM/C practice.

\begin{tabular}{|c|c|c|c|c|}
\hline \multirow[t]{2}{*}{ Characteristics } & \multicolumn{2}{|c|}{ FGM Practice } & \multirow[t]{2}{*}{ Crude Odds Ratio (95\% C.I.) } & \multirow[t]{2}{*}{$P$ value } \\
\hline & Yes & No & & \\
\hline \multicolumn{5}{|l|}{ AGE (years) } \\
\hline$\leq 19$ & $16(6.2)$ & $22(17.5)$ & 1.00 & \\
\hline $20-39$ & $157(60.9)$ & 89 (70.6) & $0.41(0.21-0.83)$ & $0.012 *$ \\
\hline $40-59$ & $74(28.7)$ & 15 (11.9) & $0.15(0.06-0.35)$ & $<0.0001 *$ \\
\hline$\geq 60$ & $11(4.3)$ & $0(0)$ & $0.00(0.00-\infty)$ & 0.999 \\
\hline \multicolumn{5}{|l|}{ TRIBE } \\
\hline Yoruba & $250(96.9)$ & $105(83.3)$ & $0.09(0.03-0.32)$ & $<0.0001 *$ \\
\hline Igbo & $5(1.9)$ & $6(4.8)$ & $0.26(0.05-1.44)$ & 0.122 \\
\hline Hausa & $0(0)$ & $1(0.8)$ & $3.46 \mathrm{E} 8(0.00-\infty)$ & 1.000 \\
\hline Others & $3(1.2)$ & $14(11.1)$ & 1.00 & \\
\hline \multicolumn{5}{|c|}{ EDUCATIONAL LEVEL } \\
\hline No formal & $8(3.1)$ & $3(2.4)$ & 1.00 & \\
\hline Primary & $10(3.9)$ & $5(4)$ & $0.75(0.20-2.92)$ & 0.683 \\
\hline Secondary & $67(26)$ & $32(25.4)$ & $1.01(0.33-3.03)$ & 0.992 \\
\hline Tertiary & $173(67.1)$ & $86(68.3)$ & $0.96(0.59-1.58)$ & 0.874 \\
\hline \multicolumn{5}{|l|}{ RELIGION } \\
\hline Christianity & $238(92.2)$ & $118(93.7)$ & 1.00 & \\
\hline Islam & $20(7.8)$ & $8(6.3)$ & $0.81(0.35-1.89)$ & 0.620 \\
\hline \multicolumn{5}{|l|}{ PARITY } \\
\hline Nullipara & $82(31.8)$ & $65(51.6)$ & 1.00 & \\
\hline Multipara & $176(68.2)$ & $61(48.4)$ & $0.44(0.28-0.68)$ & $<0.0001 *$ \\
\hline \multicolumn{5}{|c|}{ EMPLOYMENT STATUS } \\
\hline Unemployed & $34(13.2)$ & 44 (34.9) & 1.00 & \\
\hline Employed & $224(86.8)$ & $82(65.1)$ & $0.28(0.17-0.47)$ & $<0.0001 *$ \\
\hline \multicolumn{5}{|c|}{ MARITAL STATUS } \\
\hline Single & $58(22.5)$ & $57(45.2)$ & 1.00 & \\
\hline Married & $200(77.5)$ & $69(54.8)$ & $0.35(0.22-0.55)$ & $<0.0001 *$ \\
\hline \multicolumn{5}{|l|}{ OCCUPATION } \\
\hline Unemployed & $34(13.2)$ & $44(34.9)$ & 1.00 & \\
\hline Unskilled & $81(31.4)$ & $28(22.2)$ & $0.27(0.14-0.50)$ & $<0.0001 *$ \\
\hline Semi-skilled & $53(20.5)$ & $26(20.6)$ & $0.38(0.20-0.73)$ & $0.003 *$ \\
\hline Skilled & $90(34.9)$ & $28(22.2)$ & $0.24(0.13-0.45)$ & $<0.0001 *$ \\
\hline \multicolumn{5}{|c|}{ FEMALE CHILD } \\
\hline No & $113(43.8)$ & $86(68.3)$ & 1.00 & \\
\hline Yes & $145(56.2)$ & $40(31.7)$ & $0.36(0.23-0.57)$ & $<0.0001 *$ \\
\hline \multicolumn{5}{|l|}{ KNOWLEDGE } \\
\hline Poor & $235(91.1)$ & $105(83.3)$ & 1.00 & \\
\hline Fair & $18(7)$ & $14(11.1)$ & $1.74(0.83-3.63)$ & 0.140 \\
\hline Good & $5(1.9)$ & $7(5.6)$ & $3.13(0.97-10.10)$ & 0.056 \\
\hline \multicolumn{5}{|l|}{ PERCEPTION } \\
\hline Poor & $209(81)$ & $84(66.7)$ & $0.47(0.29-0.77)$ & $0.002 *$ \\
\hline Good & $49(19)$ & $42(33.3)$ & 1.00 & \\
\hline
\end{tabular}


Table 3. Multivariate logistic regression analysis of the variables influencing FGM/C practice.

\begin{tabular}{|c|c|c|c|c|}
\hline \multirow[t]{3}{*}{ Characteristics } & \multicolumn{2}{|c|}{ FGM Practice } & \multirow[t]{3}{*}{ Adjusted Odds Ratio (95\% C. I.) } & \multirow[t]{3}{*}{$P$ value } \\
\hline & Yes & No & & \\
\hline & $\mathrm{n}(\%)$ & n (\%) & & \\
\hline \multicolumn{5}{|l|}{ AGE (years) } \\
\hline$\leq 19$ & $16(6.2)$ & $22(17.5)$ & 1.00 & \\
\hline $20-39$ & $157(60.9)$ & $89(70.6)$ & $0.86(0.35-2.09)$ & 0.731 \\
\hline $40-59$ & $74(28.7)$ & $15(11.9)$ & $0.40(0.13-1.25)$ & 0.114 \\
\hline$\geq 60$ & $11(4.3)$ & $0(0)$ & $0.00(0.00-\infty)$ & 0.999 \\
\hline \multicolumn{5}{|l|}{ TRIBE } \\
\hline Yoruba & $250(96.9)$ & $105(83.3)$ & $0.07(0.02-0.25)$ & $<0.0001 *$ \\
\hline Igbo & $5(1.9)$ & $6(4.8)$ & $0.15(0.02-0.93)$ & $0.042 *$ \\
\hline Hausa & $0(0)$ & $1(0.8)$ & $1.42 \mathrm{E} 8(0.00-\infty)$ & 1.000 \\
\hline Others & $3(1.2)$ & $14(11.1)$ & 1.00 & \\
\hline \multicolumn{5}{|l|}{ PARITY } \\
\hline Nullipara & $82(31.8)$ & $65(51.6)$ & 1.00 & \\
\hline Multipara & $176(68.2)$ & $61(48.4)$ & $1.80(0.78-4.18)$ & 0.170 \\
\hline \multicolumn{5}{|c|}{ EMPLOYMENT STATUS } \\
\hline Unemployed & $34(13.2)$ & $44(34.9)$ & 1.00 & \\
\hline Employed & $224(86.8)$ & $82(65.1)$ & $0.41(0.20-0.86)$ & $0.018 *$ \\
\hline \multicolumn{5}{|c|}{ MARITAL STATUS } \\
\hline Single & $58(22.5)$ & $57(45.2)$ & 1.00 & \\
\hline Married & $200(77.5)$ & $69(54.8)$ & $0.65(0.31-1.38)$ & 0.263 \\
\hline \multicolumn{5}{|l|}{ OCCUPATION } \\
\hline Unemployed & $34(13.2)$ & $44(34.9)$ & 1.00 & \\
\hline Unskilled & $81(31.4)$ & $28(22.2)$ & $0.47(0.20-1.08)$ & 0.074 \\
\hline Semi-skilled & $53(20.5)$ & $26(20.6)$ & $0.49(0.21-1.14)$ & 0.097 \\
\hline Skilled & $90(34.9)$ & $28(22.2)$ & $0.30(0.13-0.69)$ & $0.005^{*}$ \\
\hline \multicolumn{5}{|c|}{ FEMALE CHILD } \\
\hline No & $113(43.8)$ & $86(68.3)$ & 1.00 & \\
\hline Yes & $145(56.2)$ & $40(31.7)$ & $0.52(0.25-1.07)$ & 0.076 \\
\hline \multicolumn{5}{|l|}{ PERCEPTION } \\
\hline Poor & $209(81)$ & $84(66.7)$ & $0.42(0.24-0.72)$ & $0.002 *$ \\
\hline Good & 49 (19) & $42(33.3)$ & 1.00 & \\
\hline
\end{tabular}

\section{Conclusions}

FGM/C is still commonly practiced in Ado - Ekiti, with two-thirds of the respondents having undergone one form or the other. Although most women were aware of the practice through health workers, there is an alarming rate of medicalization of FGM/C from this study. Women of Yoruba and Igbo tribes, who were employed as skilled workers, but with poor perception about FGM/C were more likely to have undergone the procedure. Scaling up awareness campaigns, increasing media involvement, legal enforcement of various acts/laws prohibiting the practice, female literacy and re-orientation to correct wrong perception about FGM/C's supposed benefits are recommended. Collecting accurate data for research into public health strategies that can lead to elimination of the practice is long overdue.

\section{Conflict of interest}

None to declare.

\section{References}

Akeju DO, OT Oladapo, M Vidler, AA Akinmade, D Sawchuck, R Qureshi, M Solarin, OO Adetoro, P von Dadelszen and the CLIP Nigeria Feasibility Working Group, 2016. Determinants of health care seeking behaviour during pregnancy in Ogun State, Nigeria. Reprod. Health., 13(Suppl 1):32.

Almroth L, H Bedri, S El Elmusharaf, A Satti, T Idris, MS Hashim, GI Suliman and S Bergström, 2005. Urogenital complications among girls with genital mutilation: A hospital-based study in Khartoum. Afr. J. Reprod. Health., 9:118-124. 
Asekun-Olarinmoye EO and OA Amusan, 2008. The impact of health education on attitudes towards female genital mutilation (FGM) in a rural Nigerian community. Eur. J. Contracept. Reprod. Health. Care., 13: 289297.

Banks E, O Meirik, T Farley, O Akande, H Bathija and M Ali, 2006. Female genital mutilation and obstetric outcome: WHO collaborative prospective study in six African countries. Lancet, 367:1835-1841.

Caldwell JC, IO Orubuloye and P Caldwell, 2000. Female genital mutilation: conditions of decline. Pop. Res. Policy. Rev., 19: 233-254.

Dare FO, VO Oboro, SO Fadiora, EO Orji, AO Sule-Odu and TO Olabode, 2004. Female genital mutilation: an analysis of 522 cases in south-western Nigeria. J. Obstet. Gynaecol., 24: 281-283.

Elnashar RA and R Abdelhady, 2007. The impact of female genital cutting on health of newly married women. Int. J. Gynaecol. Obstet., 97: 238-244.

Klouman E, R Manongi and K Klepp, 2005. Self-reported and observed female genital cutting in rural Tanzania: associated demographic factors, HIV and sexually transmitted infections. Trop. Med. Int. Health., 10: 105-115.

Larsen U and FE Okonofua, 2002. Female circumcision and obstetric complications. Int. J. Gynecol. Obstet., 77: 255-265.

Mberu BU, 2017. Female genital mutilation/cutting in Nigeria: a scoping review. Evidence to end FGM/C: Research to help women thrive. May 2017. New York: Population Council. http://www.popcouncil.org/uploads/pdfs/2017RH_FGMC-NigeriaScopingReview.pdf.

MICS Data Nigeria, 2011. Nigeria: Multiple Indicator Cluster Survey (MICS4)-2011 Nigeria, Fourth round. Abuja: National Bureau of Statistics [NBS] -Federal Government of Nigeria.

Morison L, C Schert, G Ekpo, K Paine, B West, R Coleman and G Walraven, 2001. The long-term reproductive health consequences of female genital cutting in rural Gambia: a community-based survey. Trop. Med. Int. Health., 6: 643-653.

National Population Commission (NPC) [Nigeria] and ICF International, 2014. Nigeria Demographic and Health Survey 2013. Abuja, Nigeria, and Rockville, Maryland, USA: NPC and ICF International.

National Population Commission (NPC), 2006. Population and Housing Census Priority Tables, vol 4. National Population Commission (NPC), Abuja, Nigeria. 2010.

Ogunlola IO, EO Orji and AT Owolabi, 2007. Female genital mutilation and the unborn female child in southwest Nigeria. J. Obstet. Gynaecol., 23: 143-145.

Owojuyigbe M, M Bolorunduro and D Busari, 2017. Female genital mutilation as sexual disability: perceptions of women and their spouses in Akure, Ondo State, Nigeria. Reprod. Health. Matters, 25: 80-91.

Snow RC, TE Slanger, FE Okonofua, F Oronsaye and J Wacker, 2002. Female genital cutting in southern urban and peri-urban Nigeria: self-reported validity, social determinants and secular decline. Trop. Med. Int. Health., 7: 91-100.

United Nations Children's Fund, 2016. Female Genital Mutilation/Cutting: A global concern. UNICEF, New York. http://www.unicef.org/media/files/FGMC_2016_brochure_final_UNICEF_SPREAD.pdf.

World Health Organization, 2008. Eliminating female genital mutilation: An interagency statement. OHCHR, UNAIDS, UNDP, UNECA, UNESCO, UNFPA, UNHCR, UNICEF, UNIFEM, WHO. Geneva. http://www.who.int/reproductivehealth/publications/fgm/9789241596442/en/.

Yoder P, N Abderrahim and A Zhuzhuni, 2004. Female genital cutting in the Demographic and Health Surveys: a critical and comparative analysis. DHS Comparative reports No. 7. Calverton: Macro International. 